\title{
Spatial distribuition of tooth loss in a population of adults
}

\author{
Distribuição espacial das perdas dentárias em uma população de adultos
}

\author{
Manoelito Ferreira SILVA-JUNIOR ${ }^{1}$ \\ Emílio Prado FONSECA ${ }^{2}$ \\ Marília Jesus BATISTA ${ }^{3}$ \\ Maria da Luz Rosário de SOUSA ${ }^{4}$
}

\section{ABSTRACT}

\section{Introduction}

Although there has been an improvement in the oral health status of the population, tooth loss still aggravates the oral health of adults and is a matter of great relevance to dentistry.

$\operatorname{Aim}$

To determine the spatial distribution of tooth loss in adults and correlate this with the Social Exclusion Index and proximity to public dental services.

\section{Material and Method}

This ecological study was based on epidemiological data of adults from Piracicaba municipality and from the Piracicaba Research and Planning Institute (IPPLAP). Data on dental evaluations were extracted from the Piracicaba epidemiological survey, which was a cross-sectional study with probabilistic sampling of 248 adults aged 20-64 years, representative of adults living in Piracicaba, Brazil. Oral examinations of the DMFT index were in accordance with the World Health Organization codes and criteria and were performed by a single examiner calibrated for this purpose. Data on social exclusion and the municipal health units that have dental services were extracted from IPPLAP. Georeferencing was performed of census tracts selected by draw, and the city health facilities that have dental services. For Spearman correlation analysis $(p<0.05)$, we used the mean value of teeth lost per district, the Social Exclusion Index (IEX), and proximity to public dental service categorized according to radius: $<500 m$, between $500-1000 m$, and $>1000 m$ the census tract.

\section{Result}

There was a correlation between tooth loss and higher IEX, and $r=-0.51(p=0.01)$, but no correlation with proximity to public dental services $(p=0.42)$.

\section{Conclusion}

Tooth loss in adults was distributed according to social exclusion, however, it was unrelated to proximity to the public dental services.

Keywords: Adult; Tooth Loss; Oral Health; Geographic Information Systems; Epidemiology.

\section{RESUMO}

\section{Introdução}

Embora haja uma melhoria na condição de saúde bucal da população, as perdas dentárias ainda constituem um agravo à saúde bucal de adultos e é um assunto de grande relevância para Odontologia.

\section{Objetivo}

Verificar a distribuição espacial das perdas dentárias em adultos e correlacionar com o Índice de Exclusão Social e a proximidade de serviço odontológico público.

\section{Material e Método}

Este estudo ecológico utilizou-se de dados de um levantamento epidemiológico de adultos no município de Piracicaba e do Instituto de Pesquisa e Planejamento de Piracicaba (IPPLAP). Os dados sobre as perdas dentárias foram extraídos do levantamento epidemiológico de Piracicaba, que trata-se de um estudo transversal com amostragem probabilística de 248 adultos com idade entre 20 e 64 anos, representativos dos adultos residentes em Piracicaba-SP Brasil. Os exames bucais do índice CPO-D seguiram os códigos e critérios da Organização Mundial da Saúde e foram realizados em domicílios por um único examinador calibrado para esta finalidade. Os dados sobre a exclusão social e unidades de saúde com serviço odontológico do município foram extraídos do IPPLAP. Foi realizado o georreferenciamento dos setores censitários sorteados e as unidades de saúde com serviço odontológico do município. Para análise de correlação de Spearman $(p<0,05)$, utilizou-se a média de dentes perdidos por bairro, o Índice de Exclusão Social (IEX) e a proximidade de serviço odontológico público categorizados em raio de: $<500 \mathrm{~m}$, entre 500-1000m e >1000m do setor censitário.

\section{Resultado}

Houve correlação entre a perda dentária e o maior IEX, sendo $r=-0,51(p=0,01)$, mas não houve correlação com a proximidade de serviço odontológico público $(p=0,42)$.

\section{Conclusão}

A perda dentária em adultos distribuiu-se de acordo com a exclusão social, no entanto, sem relação com a proximidade do serviço público odontológico.

Palavras-chave: Adultos; Perda de Dente; Saúde Bucal; Sistemas de Informação Geográfica; Epidemiologia.

${ }^{1}$ DDS, MS, PhD Student, Department of Community Dentistry, Dental School of Piracicaba, University of Campinas, Piracicaba, SP. Adress: Department of Community Dentistry/Piracicaba Dental School, Avenue Limeira 901, 13414-903, Piracicaba, SP, Brazil

${ }^{2}$ DDS, MS, PhD Student, Department of Community Dentistry, Dental School of Piracicaba, University of Campinas, Piracicaba, SP. Adress: Department of Community Dentistry/Piracicaba Dental School, Avenue Limeira 901, 13414-903, Piracicaba, SP, Brazil

${ }^{3}$ DDS, MS, PhD, Adjunct Professor, Faculty of Medicine Jundiaí, Jundiaí, SP, Brazil. Adress: Department of Community Health/ Faculty of Medicine Jundiaí, R. Francisco Teles, 250 - Vila Arens II, Jundiaí - SP, 13202-550, Jundiaí, SP, Brazil.

${ }^{4}$ DDS, MS, PhD, Full Professor, Department of Community Dentistry, Dental School of Piracicaba, University of Campinas, Piracicaba, SP. Adress: Department of Community Dentistry/Piracicaba Dental School, Avenue Limeira 901, 13414-903, Piracicaba, SP, Brazil 


\section{INTRODUCTION}

Although contemporary dentistry follows a conservative philosophy, tooth loss continues to be ranked among the 100 conditions that have most aggravated the health of the world population, in both 1990 and $2010^{1}$. This is because, although dental extraction is the last treatment option to be considered, in some cases, it inevitably becomes the only option².

Tooth loss has a negative impact on the quality of life of individuals, resulting from physical, psychological and/or social injury ${ }^{3,4}$. In adults it has been possible to verify the cohort effect of oral diseases, including tooth loss, because they tended to accumulate progressively throughout the course of people's lives ${ }^{2,5,6}$.

For a long time, epidemiological oral health studies have sought to identify only the microbiological causal factors in the etiology of the illness. However, due to the complexity in the health-disease process, individuallevel and contextual factors have also been associated. Tooth loss, for example, has been associated with demographic and socioeconomic aspects, health practices, and use of health services ${ }^{5,7-9}$. In this sense, populationbased epidemiological studies are important for planning strategies that achieve improvement in the oral health condition of individuals ${ }^{10}$.

In Brazil, three large epidemiological oral health surveys were conducted in 1986, 2003, and 2010, with the dental caries experience being measured by the index of permanent decayed, missing, and filled teeth (DMFT) ${ }^{11-}$ 13. In this context, it is better to study the missing tooth (M) - one of the components of this index - at the public health level, especially in the adult population.

The Geographic Information System (GIS) can be an important tool for evaluating the distribution of tooth loss, considering there are few studies that address the relationship between geographical space and oral health. This is because the distribution and location of dental services and the form of access may be related to exclusion of the population from dental care ${ }^{14}$. The delay in seeking dental treatment and possible progression of oral diseases may consequently lead to tooth loss. Geographical space is capable of determining environmental and contextual aspects, such as proximity to dental services, and geoprocessing may allow regions at greater risk to be located.

The aim of this study was to verify the spatial distribution of tooth loss in adults and correlate it with the
Social Exclusion Index and the proximity to public dental services in the city of Piracicaba-SP.

\section{MATERIALS AND METHODS}

In this ecological study, secondary data were used from the research entitled "Impact of tooth loss on the quality of life of adults" ${ }^{4}$ conducted in the city of Piracicaba, and from the Piracicaba Institute of Research and Planning (IPPLAP).

Piracicaba, a municipality located in the countryside of São Paulo, Brazil, is classified as large; in 2010, it featured a population of 364,571 inhabitants and had a high score of 0.78515 in the Municipal Human Development Index $(\text { IDHM })^{15}$.

This study was previously approved by the Research Ethics Committee of the Piracicaba Dental School, University of Campinas (number 177/2009). The sample size, calculated according to the methodology of Batista et al. ${ }^{4}$, by using a probability sample of 202,131 adults resident in Piracicaba-SP in the age group from 20 to 64 years, totaled around 240 individuals. Eleven households were selected for each of the 30 census tracts drawn.

Data were collected between June and September 2011, with the participation of one individual per residence, totaling 248 participants on conclusion of the collection. Dental caries experience was evaluated by means of the Decayed-missing-filled tooth (DMFT) index, according to the World Health Organization codes and criteria ${ }^{16}$. The survey was conducted by a single, previously calibrated examiner, with an intra-observer agreement between $96.5 \%$ and $100 \%$, and Kappa index from 0.89 to 1.

Data were tabulated in Excell $®$ spreadsheets. To analyze the data of missing teeth, the codes 4 (tooth loss due to dental caries experience) and 5 (tooth loss due to other causes) of the DMFT index were included, because the majority of the population was over 30 years of age and could not precisely recall the reason for tooth extraction. The mean $M$ values were found for each census tract drawn that participated in the study, within a total number of 30 census tracts and their corresponding districts.

In this study, the geographic unit of analysis was the city of Piracicaba-SP. Data processing and mapping were performed by means of the computer program TerraView 4.2.2. Primarily, the 30 census tracts drawn and dental care units were georeferenced, whereby it was possible to verify the proximity of the census tract to the public dental service 
within a radius of $500 \mathrm{~m}$ (Figure 1A) and $1000 \mathrm{~m}$ (Figure $1 \mathrm{~B})$. The proximity of dental services was verified according to the distance between the health units with the presence of a dental surgeon and the researched census tracts, and these were categorized into the following distances: $<500 \mathrm{~m}$, between $500-1000 \mathrm{~m}$, and $>1000 \mathrm{~m}$.
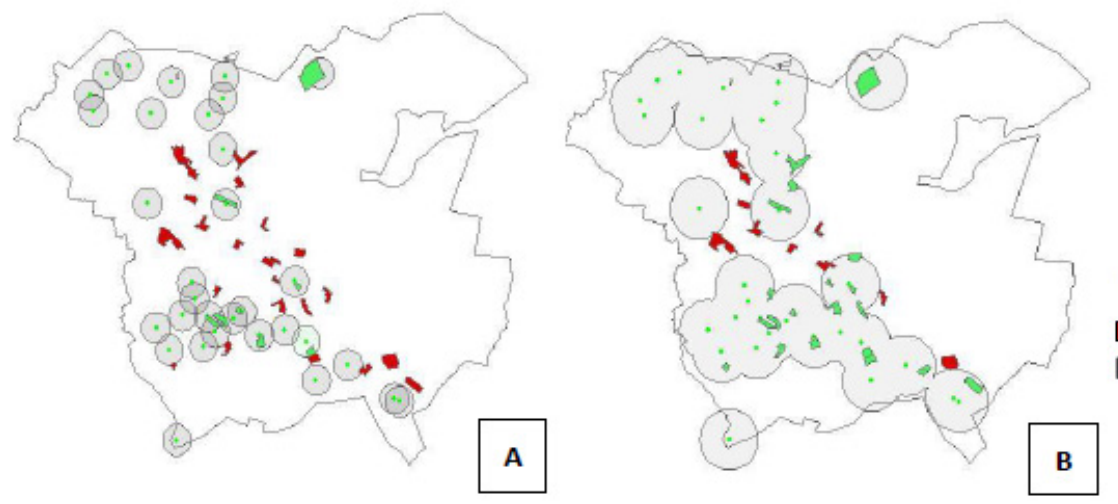

\section{Census tract}

Outside coverage area

Inside coverage area

Figure 1. Selection of census tracts with the presence of public dental services in a radius of 500 m (A) and 1000 m (B). Piracicaba-SP, Brazil, 2015.

To verify correlation with the Social Exclusion Index (IEX), established by the the Piracicaba Research and Planning Institute ${ }^{17}$ (Figure 2), the equivalence in the distribution of census tracts relative to their respective districts of the city, which totaled 24 districts, was analyzed, (Figure 3).

The IEX consists of four dimensions, namely: gender equity, human development, quality of life, and income autonomy. The scale is represented by values ranging from -1 to 1 , in which the closer to -1 , the greater the social exclusion of the district ${ }^{17}$.

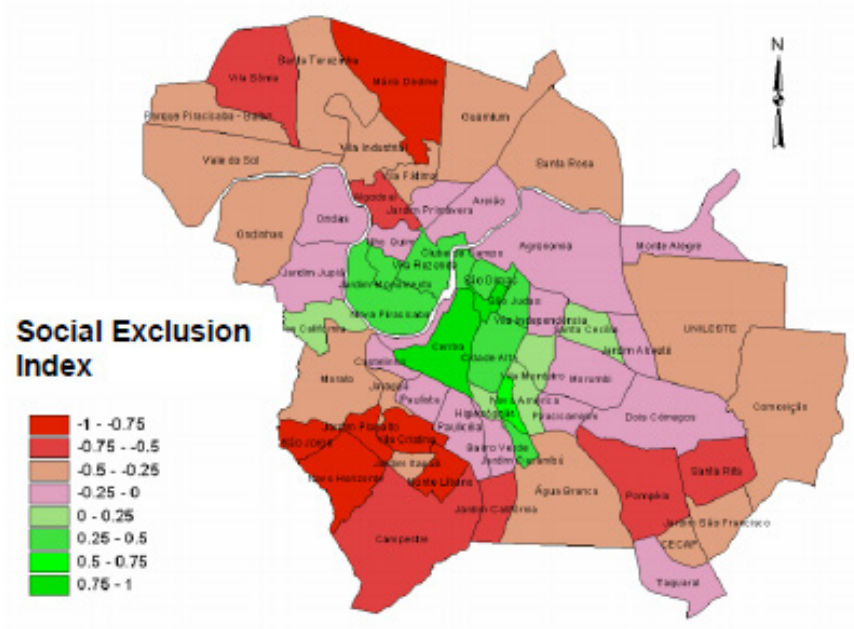

Figure 2. Social Exclusion Index (IEX) distribution in Piracicaba-SP, Brazil, 2003. SOURCE: Piracicaba Research and Planning Institute (IPPLAP), 2003.
The Bioestat 5.0 for Windows software was used for data analysis. The outcome of the study was tooth loss. For tooth loss we used the mean value found for the census tracts; the Social Exclusion Index ranged between -1 and 1 , and the proximity to public dental services was divided into three categories ( 0 for a $<500 \mathrm{~m}$ radius, 1 between 500$1000 \mathrm{~m}$, and 2 for $>1000 \mathrm{~m}$ ). Spearman's correlation with a significance level of $5 \%$ was performed among variables. A linear scatter plot was made for meaningful data.

\section{RESULTS}

In 2011, the city of Piracicaba-SP featured 34 dental service units. Figure 3 shows the geographical distribution of health units with dental services in the municipality and the distribution of the mean values of missing teeth per census tract.

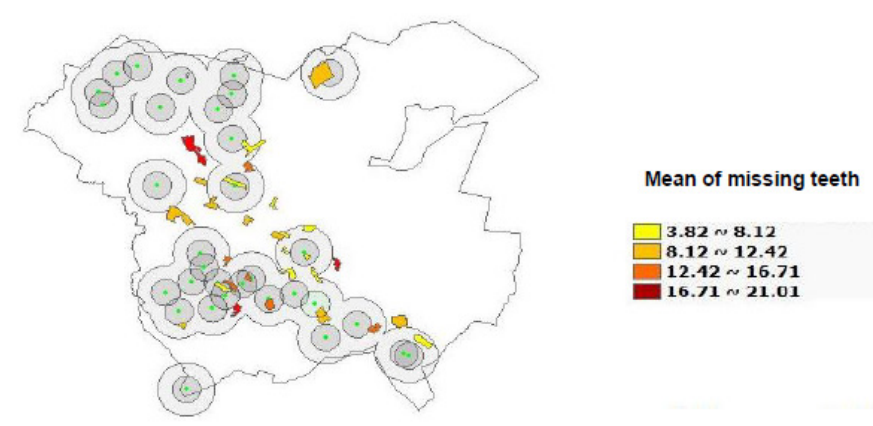

Figure 3. Distribution of the mean value of missing teeth per census tract and health units with dental services within a radius of $500 \mathrm{~m}$ and $1000 \mathrm{~m}$. Piracicaba-SP, Brazil, 2015. 
Figure 4 shows the linear scatter plot between the mean value of missing teeth per census tract and the IEX, considering there was a moderate negative correlation $(r=-0.51 ; p=0.01)$. However, there was no correlation between the mean value of missing teeth and the proximity to public dental services $(p=0.42)$.

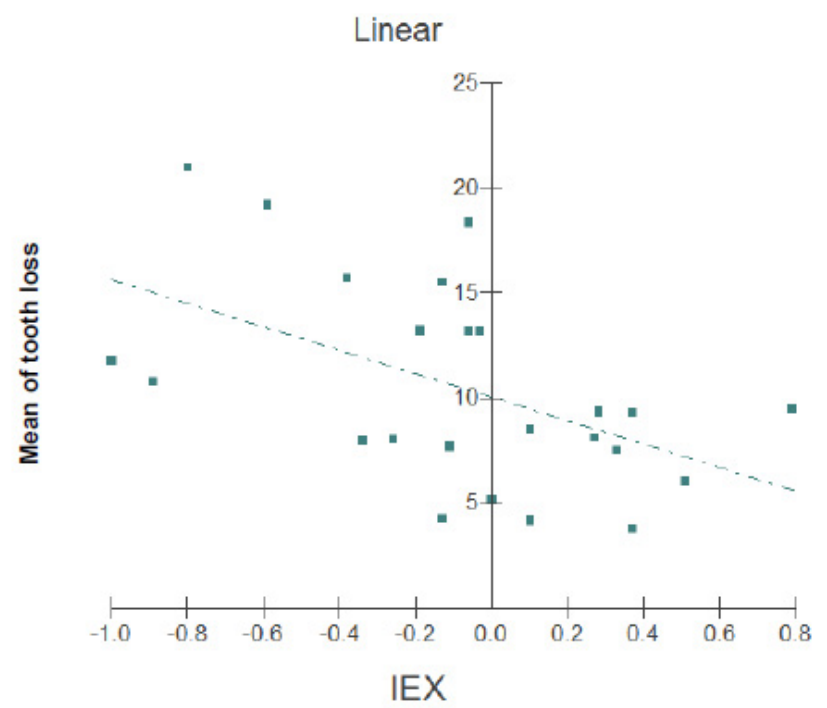

Figure 4. Linear scatter plot of the mean value of missing teeth and Social Exclusion Index (IEX) per district of Piracicaba, SP, Brazil, 2015.

\section{DISCUSSION}

In this study, it was possible to develop a Geographic Information System (GIS) containing data on the distribution of the census tracts drawn and municipal health units that featured primary dental care. Mapping made it possible to verify an uneven geographical distribution of health units with the presence of an Oral Health Team (OHT) in the city of Piracicaba-SP, showing that there was an extensive territory without coverage by dental services, which was called a "dental care void". This result indicated the need to establish more clearly defined criteria in the choice of areas that should receive health units and public dental services within the municipalities.

Geoprocessing and spatial analysis have been increasingly used as important tools in epidemiological studies. Their use, particularly during the planning of strategic health actions, could lead to better use of financial, human, and material resources, especially for vulnerable groups. In dentistry, in the existing literature this method has primarily been used relative to dental caries, periodontal disease, and edentulism ${ }^{14,18-20}$ in populations of children and older adults ${ }^{14,18,20,21}$, but it has hardly been explored in the adult population relative to tooth loss.

Indeed, dental caries, serious periodontal disease, and tooth loss are the main oral problems affecting the world population ${ }^{1}$, however, a lower proportion of studies have focused on tooth loss ${ }^{2-9}$. The age group of adults appeared to be the most suitable for studying this variable, mainly because of their longer time with permanent dentition in the oral cavity and increase in their susceptibility to oral diseases, in addition to making it possible to verify the impacts of the use of dental services by individuals over the years.

Considering that the population approach is essential for verifying health care, including dental care ${ }^{10}$, knowledge of individual and contextual factors associated with the oral health condition of individuals is important for determining health promotion strategies; the health care system provided, and the environment in which individuals are inserted ${ }^{22}$. Through mapping, it was possible to observe the distribution of dental loss in adults along with the distribution of social and economic variables. To verify the individuals surveyed at a contextual level, we used the Social Exclusion Index (IEX) per district of Piracicaba-SP.

Tooth loss showed a negative correlation with the IEX: the higher the mean value of lost teeth was, the lower was the value of the index. Other studies in PiracicabaSP have also shown a relationship between the IEX and dental caries in preschool children ${ }^{18}$ and dry mouth in older adults $^{21}$. The association between dental caries and the IEX showed the importance of the social context in determining the disease ${ }^{18}$, in addition to allowing determination of a standard of priority areas to guide efforts and planning towards oral health ${ }^{21}$.

However, in this study, tooth loss did not show a spatial (or geographical) relationship with the proximity to public dental services. Thus, macro indicators of health in this study played a very important role in determining tooth loss, considering that this was not related to access to the services. These results were relevant, because they showed that structural aspects, such as socioeconomic factors and the development of the autonomy of individuals must be considered in health promotion strategies, in addition to providing the expansion of dental services.

The lack of correlation between tooth loss and proximity to public dental services could be explained by the current Brazilian National Oral Health Policy (PNSB). The Brazilian population that is in the adult age group 
today, especially as this was a study with an expanded age group, lived though period of lack of public oral health policies in the country, particularly when considering the restrained demand; accumulation of needs, and low provision of public dental services ${ }^{2}$. Thus, although they have access to dental services nowadays, most of their tooth loss probably occurred before the implementation of this policy. Furthermore, the distribution of health dental service units may have been planned according to the number of individuals living in certain areas, and not relative to their need for health, or (as in the case of this study) for the oral health of this population. Another theory that might support this idea is the traumatic and mutilative approach to dentistry in the past, which could reflect the delay in seeking dental services or in the case of dental emergencies. This is because tooth losses have a cohort effect, since they accumulate over the lifetime of individuals, without any natural association with aging, but due to the aggravation of oral diseases ${ }^{5}$. Not associating the access The fact of access to public or private dental services not being associated with tooth loss could be explained by both the easy access to the services, and by individuals' exclusion from them: because this could culminate in overtreatment and repetitive restorative cycles ${ }^{23}$, or delayed request for and access to dental care, with progression of the disease, respectively, resulting in tooth extraction as the only treatment option ${ }^{24}$.

The authors emphasize that the big questions, as we have seen in other studies, are individual and cultural aspects that lead to the choice of tooth loss and health literacy, i.e., the individual knowledge of each person determining the personal choices that are intrinsically connected with empowerment. More important than providing dental services are health promotion policies, as determined by the Ottawa Charter ${ }^{25}$, which should promote training and co-responsibility of individuals, through strategies that increase their autonomy in making healthy choices for both health practices and the use of health services.

\section{REFERENCES}

1. Marcenes W, Kassebaum NJ, Bernabé E, Flaxman A, Naghavi M, Lopez A, Murray CJ. Global Burden of Oral Conditions in 19902010: a systematic analysis. J Dent Res 2013; 92 (7): 592-597.

2. Silva-Junior MF, Souza ACC, Batista MJ, Sousa MLR. Oral health condition and reasons for tooth extraction among an adult population (20-64 years). Cienc Saude Coletiva. 2016. In press.
The limitation of the study was related to the inability of cross-sectional studies to infer some events: considering that they simultaneously assess the people who already have the disease, without being able to determine the time the disease occurred. Although this study could not establish the causality for tooth loss, it could indicate the associated factors, mainly the role of health determinants in the occurrence of tooth loss.

\section{CONCLUSION}

The spatial distribution of tooth loss in adults of Piracicaba-SP was correlated with the current social exclusion in the municipality, but not with the proximity to public dental services. This spatial analysis of tooth loss provided consistent data for planning oral health policies and implementing public dental services consistent with the needs of the population studied.

\section{Acknowledgements}

The authors would like to thank Fundação de Amparo à Pesquisa do Estado de São Paulo (São Paulo Research Foundation) - FAPESP (2009/16560-0, 2011/00545-1) and the Cooperation agreement with FAPESP and Coordenação de Aperfeiçoamento de Pessoal de Nivel Superior (Coordination of Higher Education and Graduate Training) - CAPES (2014/15184-2) for supporting this research. The authors also thank Espaço da Escrita Coordenadoria Geral da Universidade - UNICAMP - for the translation services.

\section{Collaborators}

MF Silva-Junior and EP Fonseca performed the data analysis and writing the article, MJ Batista collected the data and performed the final review of article, MLR Sousa guided at all stages of the collection and did the final review of the article.

3. Gerritsen AE, Allen PF, Witter DJ, Bronkhorst EM, Creugers NHJ. Tooth loss and oral health-related quality of life: a systematic review and meta-analysis. Health Qual Life Outcomes 2010; 8:126.

4. Batista MJ, Lawrence HP, Sousa MLR. Impact of tooth loss related to number and position on oral health quality of life among adults. Health Qual Life Outcomes 2014, 12:165.

5. Batista MJ, Rihs LB, Sousa MLR. Risk indicators for tooth loss in adult workers. Braz Oral Res 2012; 26(5): 390-396. 
6. Kassebaum NJ, Bernabé E, Dahiya M, Bhandari B, Murray CJL, Marcenes W. Global Burden of severe tooth loss: a systematic review and meta-analysis. J Dent Res 2014; 93 (Suppl 1): 20-28.

7. Barbato PR, Nagano HCM, Zanchet FN, Boing AF, Peres MA. Tooth loss and associated socioeconomic, demographic, and dental-care factors in Brazilian adults: an analysis of the Brazilian Oral Health Survey, 2002-2003. Cad Saúde Pública 2007; 23(8): 1803-1814.

8. Silva EA, Tôrres LHN, Sousa MLR. Tooth loss and impact on quality of life in adult users of two Basic Health Units. Rev Odontol UNESP 2012; 41(3): 177-184.

9. Moreira RS, Nico LS, Barrozo LV, Pereira JCR. Tooth loss in Brazilian middle-aged adults: multilevel effects. Acta Odontol Scand 2010; 68 (5):269-277.

10. McGrath C, Lawrence HP, Blinkhorn A. Guest editorial on the Festchrift "Challenges in population oral health for the 21st Century". Community Dent Oral Epidemiol 2012; 40 (Suppl. 2):1-4.

11. Brasil. Ministério da Saúde. Divisão Nacional de Saúde Bucal. Levantamento epidemiológico em saúde bucal: Brasil, zona urbana 1986. Brasília: MS; 1988. (Série C: Estudos e Projetos, 4).

12. Brasil. Ministério da Saúde. Secretaria de Atenção à Saúde. Departamento de Atenção Básica. Projeto SB Brasil 2003: condições de saúde bucal da população brasileira 2002-2003: resultados principais. Brasília: MS; 2004. (Série C. Projetos, Programas e Relatórios).

13. Brasil. Ministério da Saúde. Secretaria de Atenção à Saúde. Departamento de Atenção Básica. Projeto SB Brasil 2010: condições de saúde bucal da população brasileira 2010-2011: resultados principais. Brasília: MS; 2011. (Série C. Projetos, Programas e Relatórios).

14. Moreira RS, Nico LS, Tomita NE. Spatial risk and factors associated with edentulism among elderly persons in Southeast Brazil. Cad Saúde Pública 2011, 27(10): 2041-2054.

15. Instituto Brasileiro de Geografia e Estatísticas (IBGE). Censo demográfico 2000: Características da população e dos domicílios. [Access on Mar. 10, 2010]. Available from: www. ibge.gov.br.

16. World Health Organization. Oral heath surveys: basic methods 4th ed. Geneva: World Heath Organization; 1997.
17. Instituto de Pesquisa e Planejamento de Piracicaba. Mapa de exclusão/inclusão social de Piracicaba. [Access on Nov. 20, 2012]. Available from http://www.ipplap.com.br.

18. Pereira SM, Pardi $V$, Cortellazzi $\mathrm{KL}$, Bovi Ambrosano GM, Vettorazzi CA, Ferraz SFB, Meneghim MC, Pereira AC. Geographic information system and multilevel analysis: gingival status among 12-year-old schoolchildren in São Paulo, Brazil. Rev Panam Salud Publica 2014; 35(2): 136-143.

19. Ely HC, Abegg C, Rosa AR, Pattussi MP. Dental caries reduction among adolescents: temporal and spatial distribution in 36 Southern Brazilian municipalities, 2003 and 2011. Epidemiol Serv Saúde 2014; 23 (3): 421-434.

20. Hewlett SA, Calys-Tagoe BN, Yawson AE, Dako-Gyeke P, Nakua E, Folson G, Baddo AN, Mensah G, Minicuci N, Kowal P, Biritwum RB. Prevalence and geographic distribution of edentulism among older Ghanaians. J Public Health Dent. 2015; 75 (1):74-83.

21. Costa AM, Fonseca EP, Fonseca DAV, Sousa MLR. Spatial distribution of xerostomia and social exclusion index of elderly patients in Piracicaba, SP, Brazil. Arq Odontol 2015; 51(1): 3946.

22. Batchelor P. What do we mean by population health? Community Dent Oral Epidemiol 2012; 40 (Suppl. 2): 12-15.

23. Elderton, RJ. Preventive (Evidence-Based) approach to quality general dental care. Med Princ Pract 2003;12 (suppl 1):12-21.

24. Lacerda JT, Simionato EM, Peres KG, Peres MA, Traebert J, Marcenes W. Dental pain as the reason for visiting a dentist in a Brazilian adult population. Rev Saude Publica 2004; 38(3): 453458.

25. World Health Organization. Ottawa Charter for Health Promotion. [access on July 28, 2015]. Available from: http:// www.who.int/hpr/docs/ottawa.html.

Received on: 16/2/2016

Final version resubmitted on: 9/12/2016

Approved on: 19/12/2016 